\title{
Front Matter: Volume 11349
}

, "Front Matter: Volume 11349," Proc. SPIE 11349, 3D Printed Optics and Additive Photonic Manufacturing II, 1134901 (14 April 2020); doi:

$10.1117 / 12.2571662$

SPIE. Event: SPIE Photonics Europe, 2020, Online Only 




\title{
3D Printed Optics and Additive Photonic Manufacturing II
}

\author{
Alois M. Herkommer \\ Georg von Freymann \\ Manuel Flury \\ Editors \\ 6-10 April 2020 \\ Online Only, France \\ Sponsored by \\ SPIE \\ Cosponsored by \\ City of Strasbourg (France) \\ Eurometropole (France) \\ CNRS (France) \\ iCube (France) \\ Université de Strasbourg (France) \\ Cooperating Organisations \\ Photonics 21 (Germany) \\ EOS-European Optical Society (Germany) \\ Photonics Public Private Partnership (Belgium) \\ Photonics France (France) \\ Published by \\ SPIE
}

Volume 11349 
The papers in this volume were part of the technical conference cited on the cover and title page. Papers were selected and subject to review by the editors and conference program committee. Some conference presentations may not be available for publication. Additional papers and presentation recordings may be available online in the SPIE Digital Library at SPIEDigitalLibrary.org.

The papers reflect the work and thoughts of the authors and are published herein as submitted. The publisher is not responsible for the validity of the information or for any outcomes resulting from reliance thereon.

Please use the following format to cite material from these proceedings:

Author(s), "Title of Paper," in 3D Printed Optics and Additive Photonic Manufacturing II, edited by Alois M. Herkommer, Georg von Freymann, Manuel Flury, Proceedings of SPIE Vol. 11349 (SPIE, Bellingham, WA, 2020) Seven-digit Article CID Number.

ISSN: 0277-786X

ISSN: 1996-756X (electronic)

ISBN: 9781510634701

ISBN: 9781510634718 (electronic)

Published by

SPIE

P.O. Box 10, Bellingham, Washington 98227-0010 USA

Telephone +1 3606763290 (Pacific Time) · Fax +1 3606471445

SPIE.org

Copyright (c) 2020, Society of Photo-Optical Instrumentation Engineers.

Copying of material in this book for internal or personal use, or for the internal or personal use of specific clients, beyond the fair use provisions granted by the U.S. Copyright Law is authorized by SPIE subject to payment of copying fees. The Transactional Reporting Service base fee for this volume is $\$ 21.00$ per article (or portion thereof), which should be paid directly to the Copyright Clearance Center (CCC), 222 Rosewood Drive, Danvers, MA 01923. Payment may also be made electronically through CCC Online at copyright.com. Other copying for republication, resale, advertising or promotion, or any form of systematic or multiple reproduction of any material in this book is prohibited except with permission in writing from the publisher. The CCC fee code is 0277$786 \mathrm{X} / 20 / \$ 21.00$.

Printed in the United States of America by Curran Associates, Inc., under license from SPIE.

Publication of record for individual papers is online in the SPIE Digital Library.

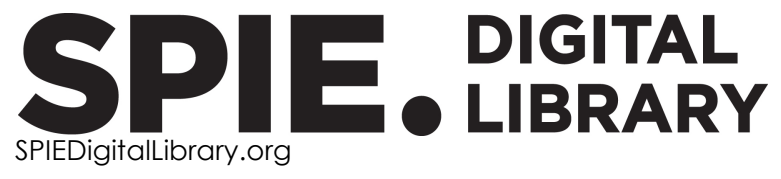

Paper Numbering: Proceedings of SPIE follow an e-First publication model. A unique citation identifier (CID) number is assigned to each article at the time of publication. Utilization of CIDs allows articles to be fully citable as soon as they are published online, and connects the same identifier to all online and print versions of the publication. SPIE uses a seven-digit CID article numbering system structured as follows:

- The first five digits correspond to the SPIE volume number.

- The last two digits indicate publication order within the volume using a Base 36 numbering system employing both numerals and letters. These two-number sets start with 00, 01, 02, 03, 04, $05,06,07,08,09,0 A, 0 B \ldots$ OZ, followed by 10-1Z, 20-2Z, etc. The CID Number appears on each page of the manuscript. 


\title{
Contents
}

\author{
$\checkmark \quad$ Authors \\ vii Conference Committee
}

\section{FIBRES AND INTERCONNECTS}

$1134907 \quad$ Mode-field matching design, 3D fabrication and characterization of down-tapers on singlemode optical fiber tips for coupling to photonic integrated circuits [11349-9]

1134909 Generation of functional curved waveguides by $\mathrm{CO}_{2}$-laser based deposition of coreless fused silica fibers [1 1349-11]

11349 OA Stereolithographic printed polymers on ceramic for 3D-opto-MID [11349-12]

3D PRINTED METALS AND CERAMICS

11349 OC Additive manufacturing of copper-molybdenum pseudoalloys [11349-14]

3D PRINTING OF MACRO-OPTICS

11349 OG Mode-locked diode lasers as sources for two-photon polymerization [11349-18]

\section{POSTER SESSION}

11349 OM Design and prototyping of beam shapers to generate circular or square top-hat beams of different size for additive manufacturing applications [11349-24]

11349 ON Manufacturing and analyzing of cost-efficient fresnel lenses using stereolithography [11349-25]

1134900 Proximity effect in parallelized microfabrication using two-photon polymerization [1 1349-26]

$11349 \mathrm{OP} \quad$ Laser forming of tissue-engineering structures with nanocarbon scaffolds in the bioorganic matter [1 1349-27]

11349 OT Additive manufacturing of magnetic materials using selective laser melting [11349-31]

11349 OU Laser formation of electrically conductive nanocomposites for bioelectronic applications [11349-32] 
Proc. of SPIE Vol. 11349 1134901-4 Downloaded From: https://www.spiedigitallibrary.org/conference-proceedings-of-spie on 26 Apr 2023
Terms of Use: https://www.spiedigitallibrary.org/terms-of-use 


\section{Authors}

Numbers in the index correspond to the last two digits of the seven-digit citation identifier (CID) article numbering system used in Proceedings of SPIE. The first five digits reflect the volume number. Base 36 numbering is employed for the last two digits and indicates the order of articles within the volume. Numbers start with 00, 01, 02, 03, 04, 05, 06, 07, 08, 09, 0A, 0B...0Z, followed by 10-1Z, 20-2Z, etc.

Ackstaller, Thomas, OA

Arnoux, C., 00

Baldeck, P., 00

Bayard, B., OT

Belay, Gebirie Y., OM

Bernhard, R., OC

Beyer, Micha, ON

Blinova, Ekaterina $V$., OP

Bock, Karlheinz, OA

Bychkov, V. N., OU

Capraro, S., OT

Carlier, Q., 00

Chatelon, J. P., ОT

Cherepanova, N. G., OU

Craeghs, Tom, OM

Demidenko, N. A., OU

Demura, Tatiana A., OP

Dudin, A. A., OU

Dzhalilov, Siradzh I., OP

Eganova, Elena M., OP, OU

Esen, C., OG

Fedorova, Yulia O., OP

Gerasimenko, Alexander Yu., OP, OU

Gurevich, E. L., OG

Heggarty, K., 00

Hermsdorf, J., OC

Hoff, C., OC

Hofmann, M. R., OG

Hohnholz, Arndt, 09

Jäschke, Peter, 09

Kaierle, S., OC

Khaldi, A., 00

Klehr, A., OG

Knigge, A., OG

Komarchev, A. S., OU

Kracht, Dietmar, 09

Kranert, Fabian, 09

Kuksin, A. V., OU

Kurilova, Ulyana E., OP

Lachmayer, Roland, 09

Liao, Sijie, OM

Lorenz, Lukas, OA

Markov, Alexandr G., OP

Morozov, Michail A., OP

Murashko, D. T., OU

Neef, P., OC

Neumann, Jörg, 09

Obeid, B., OT

Ostendorf, A., OG
Panapakkam, Vivek, 07

Pavlov, A. A., OU

Pérez Covarrubias, L., 00

Piétroy, D., OT

Rettschlag, Katharina, 09

Rousseau, J. J., OT

Saurav, Kumar, 07

Semak, A. E., OU

Shrotri, Abhijeet, ON

Stübbe, Oliver, ON

Surkamp, N., OG

Thienpont, Hugo, 07, OM

Van den Ecker, Piet, OM

Van Erps, Jürgen, 07, OM

Van Thourhout, Dries, 07

Vanmol, Koen, 07

Vermeulen, Nathalie, 07

Vervaeke, Michael, OM

Watté, Jan, 07

Wesling, $\mathrm{V} ., \mathrm{OC}$

Wiche, H., OC

Wienke, Andreas, 09

Zhurbina, Natalia N., OP

Zyla, G., OG 
Proc. of SPIE Vol. 11349 1134901-6 Downloaded From: https://www.spiedigitallibrary.org/conference-proceedings-of-spie on 26 Apr 2023
Terms of Use: https://www.spiedigitallibrary.org/terms-of-use 


\section{Conference Committee}

Symposium Chairs

Francis Berghmans, Vrije Universiteit Brussel (Belgium)

Thierry Georges, Oxxius SA (France)

Paul Montgomery, Université de Strasbourg (France)

Lluis Torner, ICFO Barcelona (Spain)

Conference Chairs

Alois M. Herkommer, Universität Stuttgart (Germany)

Georg von Freymann, Technische Universität Kaiserslautern (Germany)

Manuel Flury, Institut National des Sciences Appliquées de Strasbourg (France)

\section{Conference Programme Committee}

Klaus Bade, Karlsruher Institut für Technologie (Germany)

Muriel Carin, Université de Bretagne Sud (France)

Thierry Engel, IREPA LASER (France)

Harald Giessen, Universität Stuttgart (Germany)

Kevin J. Heggarty, Télécom Bretagne (France)

Andreas Heinrich, Hochschule Aalen - Technik und Wirtschaft (Germany)

Hans Peter Herzig, Ecole Polytechnique Fédérale de Lausanne (Switzerland)

Christian Koos, Karlsruher Institut für Technologie (Germany)

David Pietroy, Université Jean Monnet Saint-Etienne (France)

Michael Thiel, Nanoscribe GmbH (Germany)

Michael Totzeck, Carl Zeiss SMT GmbH (Germany)

Reinhard Voelkel, SUSS MicroOptics SA (Switzerland) 
Proc. of SPIE Vol. 11349 1134901-8 Downloaded From: https://www.spiedigitallibrary.org/conference-proceedings-of-spie on 26 Apr 2023
Terms of Use: https://www.spiedigitallibrary.org/terms-of-use 